\title{
Analysis of the Altilis Cookies Startup Business Method Using the Canvas Model as a Business Development Effort to Provide Gluten and Casein Free Snacks for Autistic Children
}

\author{
Haura Annisaa Salsabila ${ }^{\text {* }}$, Kiyoko Kylanisa Razzaq Firdausi ${ }^{1}$, Marsindi ${ }^{1}$, Junita Al \\ Fora $^{2}$, Mohammad Fariz Rizki Muliawan ${ }^{3}$, Dias Pratami Putri ${ }^{1}$ \\ ${ }^{1}$ Indonesia University of Education, Catering Industry Management, Jl. Dr. Setiabudhi No. \\ 229, Indonesia \\ ${ }^{2}$ Indonesia University of Education, Special Education, Jl. Dr. Setiabudhi No. 229, Indonesia \\ ${ }^{3}$ Indonesia University of Education, Visual Communication Design, Jl. Dr. Setiabudhi No. \\ 229, Indonesia \\ *Corresponding Author.E-mail:hauraannisas@upi.edu
}

ABSTRACT
Culinary advancement is increasing year after year. This development is consistent with
the rise of pioneering culinary businesses. This culinary development occurs not only in general
but also in the development of special foods for autism. Altilis cookies is a startup that sells
GFCF (Gluten Free Casein Free) snacks made with breadfruit flour as the main ingredient.
Altilis cookies, as a new company, requires a helpful business model analysis to serve as a
benchmark for future growth. Using a business approach, the canvas model can build and
develop a business that can be created, given, and doubled in value by utilizing the nine existing
blocks (Narto, 2017:105). The research method used in this journal is quantitative descriptive.
Primary and secondary sources are used to collect data. The purposive sampling method is used
to determine informants, which is the technique of deciding informants based on the subjective
considerations of researchers (Sugiyono, 2012). The application of this canvas business model
is intended to facilitate the business development process because it contains elements with
attachments, which are, of course, critical for business progress.
Keywords: business model canvas; autism; food; cookies; strategy
First Received: April $2021 \quad$ Pevised: May $\mathbf{2 0 2 1}$
Final Proof Received: June 2021
Accepted: May 2021




\section{Introduction}

Food is inextricably linked to human existence. The growing age of food is not only interpreted as a need-satisfying activity but has also evolved into a way of life and tourism known as culinary tourism. Culinary is derived from the English word culinary, which means "concerning cooking." In Indonesia, the term culinary has evolved to refer to the profession of a chef or cook.

Opportunity try to open a business in the culinary field to produce MSMEs (Micro, Small, and Medium Enterprises) in the culinary area with various foods on offer. It makes business actors do culinary a business that can generate a lot of profits. Not only in general, but culinary developments also grow in special foods for people with autism. Many studies have been carried out to find food substitutes for food substitutes prohibited for consumption for people with autism.

Autistic Spectrum Disorder (ASD) is a pervasive developmental disorder characterized by an inability to interact socially, communicate, and behave appropriately for one's age, interests, and activities. These abnormalities are discovered before the child reaches the age of three (Nurhidayati, 2015). Parents play an essential role in their child's development and should always consult a doctor to monitor their development. Autism patients' diets must also be considered. Food influences the behavior of autistic children, such as hyperactivity and self-harm. Many foods are off-limits to people with autism. Foods containing gluten, casein, soybeans, yeast, and chemicals are all off-limits to people with autism. Gluten can be found in wheatcontaining foods, whereas casein can be found in cow's milk-containing foods such as milk, yogurt, and cheese.

Altilis cookies is a new startup that provides snacks that are suitable for children with autism. In general, cookies are made with wheat flour and contain milk and butter as fillers. This is one of the taboo topics for autistic children. Altilis cookies offers snacks made with breadfruit flour rather than butter or milk. Altilis cookies, as a new startup, requires careful planning to run its business. Analysis of a company can assist business actors in carrying out their business operations; additionally, when the business encounters problems, business actors can make decisions based on the analysis that has been completed.

The canvas business model is a well-known business model. The canvas business model is still being implemented to improve the current business model (Adebei \& Avison, 2010; Nenonen \& Storbacka, 2010; Smedlund, 2012; Kindstrom \& Kowalkowski, 2014; Haaker, 2017; Ojasalo, 2018). The business model canvas makes it simple to see how the business model will be implemented; using this model, business actors can easily find every element related to the business presented in complete and detail. Given the Altilis cookies snack business's potential, it is necessary to examine the Altilis cookies business model planning.

\section{Literature Review}

\subsection{Autism}

Children with special needs are children who have different unique characteristics than other children but do not always exhibit mental, emotional, or physical disabilities (Geniofam, 2010). Autism Spectrum Disorder is one type of special needs child (ASD). In general, Autism Spectrum Disorder (ASD), also known as autism, is a catch-all term for various diseases associated with developmental disorders. Autism is derived from the words autos, which means "self," and ism, which means "understanding" or "flow." Autism is derived from the Greek word cars, which means "alone." Children with autism appear to live in their world, avoiding social contact and living a life in 
their imagination. Leo Kanner was the first to discover autism in 1943. Kanner (1943) defined this disorder as an inability to interact with others, a language disorder characterized by delayed language acquisition, echolalia (frequently heard resonating sounds), sentence reversals, activity repetitive and stereotyped play, vital memory routes, and an obsessive desire to maintain order in the environment.

According to the Centers for Disease Control and Prevention (CDC), there are 4.5 times more autistic boys than autistic girls in the United States. This is since men produce more testosterone than women. The testosterone hormone inhibits the function of RORA (Retinoic Acid Related Orphan Receptor Alpha), a gene that regulates brain function and protects nerve cells from stress, causing cells to malfunction.

According to data from the Centers for Disease Control (CDC) in America, the prevalence of children with autism spectrum disorders in 2018 is estimated to be one in 59 children, a $15 \%$ increase from one in 68 children in 2014. Meanwhile, according to the World Health Organization, one out of every 160 children worldwide suffers from autism spectrum disorders. Autism prevalence in Indonesia has risen dramatically, from 1 per 1000 population to 8 per 1000 population, exceeding the global average of 6 per 1000 population.

Characteristics of autism disorders in some individuals have started to appear in infancy. A prominent feature is the absence of eye contact and minimal reaction to his mother or caregivers. In another small proportion of individuals with autism, development has occurred in a "relatively normal" manner. Children will have developmental disorders in three aspects, namely quality in behavior, social and emotional interaction skills, poor quality in reciprocal communication skills, and limited interests accompanied by repetitive movements without purpose.
(Simbolon, dkk, 2020: 506)

There is no specific treatment for autism. Therapy is one of the most effective ways to treat autistic children's behavior disorders. Autistic children receive occupational therapy, sensory integration therapy, speech therapy, music therapy, and physical therapy to help them cope with the behavioral disorders they face daily. Furthermore, several dietary treatments for autistic children have been developed. Autistic children can benefit from a glutenfree, casein-free diet, a specific carbohydrate diet, an antiyeast/fermentation diet, and food intolerances in the form of preservatives, food coloring agents, and food flavor enhancers (additives). The disadvantage of this diet therapy is that it is not entirely appropriate for children with autism. Because the causes or etiology of behavioral disorders are so diverse, one treatment may help one child but not another. (Khoirunnisa, Judiono, 2018: 2)

\subsection{GFCF Food}

One of the studies that have been done on autism is about consumption patterns for people with autism, namely a gluten-free and casein-free diet or GFCF (Gluten-free Casein-free). This diet can improve indigestion and reduce autistic symptoms or behavior. Gluten and casein are challenging to digest, so children with autism should avoid preparations made from these two proteins. (Tanjung, dkk, 2015: 11)

Sugar, cow's milk, wheat, chocolate, eggs, nuts, and fish are among the foods that cause allergic reactions in autistic children. Gluten is a protein found primarily in wheat flour and in trace amounts in other cereal flours. Gluten is made up of two protein components: gliadin and gluten. While casein is a complex protein found in milk that can agglomerate and form a compact mass. (Nurhidayati, 2015:124) Factors that cause high intake are external factors originating 
from the environment outside the home/school and advertisements from print and electronic media. Most snacks sold around the environment outside the home/school contain gluten and casein. (Khoirunnisa, Judiono, 2018:7)

Good food for ASD children is generally the same as good food for other children, namely foods with balanced nutrition and the need to consider aspects of food selection. A gluten-free and caseinfree diet is typically prescribed for children with ASD. Although implementing this diet is difficult due to obstacles avoiding popular western foods among children, such as fried chicken, hamburgers, and pizza, which all contain a lot of gluten. Ice cream and milk chocolate should also be avoided because they contain casein. The limited variety of products made from other than gluten and casein that children like is another problem that has resurfaced. (Pusphita, Berawi, 2016: 39)

The fisher's exact test results published in the journal Research on the Relationship between Gluten and Casein Consumption Patterns, Compliance with the Gluten-Free Casein-Free (GFCG) Diet with Autistic Behavior at Bekasi Autism House revealed a link between gluten consumption patterns and autistic behavior. The more frequently autistic children consume gluten-containing foods, the more severe their autistic behavior will be. (Djati, Ahmad Faridi \& Nur S Rahayu, 2017)

\subsection{Bussines Model Canvas}

The fisher's exact test results published in the journal Research on the Relationship between Gluten and Casein Consumption Patterns, Compliance with the Gluten-Free Casein-Free (GFCG) Diet with Autistic Behavior at Bekasi Autism House revealed a link between gluten consumption patterns and autistic behavior. The more frequently autistic children consume gluten-containing foods, the more severe their autistic behavior will be. (Narto, 2017:105).
This business model canvas includes nine elements: customer segments, value propositions, channels, customer relationships, revenue streams, essential resources, key activities, key partnerships, and cost structure (Osterwalder, Pigneur, 2010). The nine elements in the business model canvas are vital and attached, allowing them to present an understandable and practical analysis. The business model canvas strategy can be used to determine the company's strategy effectively and efficiently. (Hartatik \& Baroto, 2017:113).

Customer segments are the parties who are the intended market for the products or services provided by business actors. Consumer segmentation is the first thing that must be ensured in a market model business because consumers will buy or use the products and services offered, and a company may not be able to survive without consumers.

Value propositions are the benefits or uniqueness of services and products. The products available are capable of resolving problems and meeting the needs of target consumers. The benefits and identity of the products offered can be a differentiating value compared to other similar products.

Channels are the connecting elements for business actors to convey the value propositions of the products and services offered. The channel here describes how the company communicates and reaches its customer segments (Osterwalder \& Pigneur 2010). Channels include ways to increase awareness, make it easier for customers to assess, help customers buy their products or services, deliver their products or services, and provide after-sales assistance. (Fitriani \& Sultan, 2019)

A customer relationship is a relationship with consumers. It aims to get new consumers or keep old customers to continue sustainably using the product or service.

The flow of funds that becomes financial flows within the company is 
referred to as revenue streams. The incoming flow is generated by the customer segment and is then replayed on operating costs to generate profits.

The term "key resources" refers to the essential assets that determine the success of a business model. These valuable assets allow the organization to deliver on the value proposition that it promises to its customers. Physical resources (buildings, vehicles, and equipment), money, intellectual assets (brands, copyrights, patents, and customer databases), and human resources are all examples of crucial resources. Academic resources are one of the most valuable of these four assets because they are challenging to imitate. (Fitriani \& Sultan, 2019)

Key activities are activities carried out to achieve the success of a business. This element will describe what the company will do to make the business model designed to work, such as production, problem-solving, platform, and network activities used. (Osterwalder \& Pigneur 2010)

Key activities play an essential role in producing product uniqueness. Key partnerships are partners who help each other and benefit from each other.

The cost structure includes all of the costs associated with running a business. The cost structure is influenced by the company strategy, which may prioritize low costs or unique benefits. Furthermore, the size of fixed costs, variable costs, and economies of scale all impact the cost structure (economy and in the form of repetition). Sales of products or services are examples of transactional income, while asset rentals, subscriptions, and memberships are examples of repetitive income (Fitriani \& Sultan, 2019). Managing costs effectively will increase the efficiency of our business and reduce the risk of loss. This section of the cost structure explains all of the expenses incurred to run the designed business model. (Osterwalder \& Pigneur 2010)

\section{Research Method}

The method used in this Research is the descriptive quantitative method. Data collection uses primary and secondary sources. The technique of determining the informant uses the purposive sampling method, namely the method of determining the informant based on the subjective considerations of the researcher (Sugiyono, 2013).

\section{Result and Discussion}

The business model canvas is a framework that works to make it easier to visualize ideas in the form of blocks contained within the framework. The business model canvas was first introduced in the book Business Model Generation by Alexander Osterwalder.

The business model canvas depicts a straightforward business model flow. Each groove connects one element to the next. This business model can be used by any type of company, regardless of industry.

The canvas business model mapping in Altilis cookies contains nine interrelated elements. The first element is consumer segmentation. Altilis cookies consumer segmentation serves to determine consumer needs so that Altilis cookies products can meet the needs of the intended consumers. Consumer segmentation (Customer Segment) Altilis cookies are mothers who have children with autism with middle to lower economic status, live in urban areas, especially Bandung Raya, and have a high level of selectivity towards food choices for autistic children.

Altilis cookies have an exciting shape, namely ten types of endemic animals in Indonesia. It can be of educational value for children to introduce endemic animal species through cookies. In addition to the packaging of Altilis cookies , a QR code can be scanned by people children's parents through their cell phones. 
The QR code will be linked directly to the Altilis cookies website and display pictures and descriptions of the ten endemic animals. Altilis cookies are made from breadfruit flour which is the primary raw material, and made from other ingredients that are gluten and casein free, so it is safe for children with autism. The packaging used has an attractive, practical, and safe design. This is the advantage of Altilis cookies which can become a value proposition element in canvas business analysis.

Altilis cookies utilizes social media as a channel (distribution channel). Facebook, Instagram, and E-Commerce are channel elements because most of the target consumers of Altilis cookies are mothers or parents who have technological behavior patterns that can take advantage of technology, especially in social media. Customer relationships maintain relationships with customers both offline and online (Osterwalder \& Pigneur 2010, Fatricia \& Mokh, Adib, 2019:97). Customer relationship aims to make consumers able to be loyal by buying the products offered. Thus business actors must maintain excellent and consistent relationships with the quality of the products or services provided. In maintaining good relations with customers, Altilis cookies strives to maintain quality and good connections with consumers. This is done through full service, article updates, or uploads of information about autism and gluten and casein-free diet.

Revenue Streams describe how the organization earns money from each customer segment. This flow of funds allows the organization to survive (Fitriani $\&$ Sultan, 2019). The source of income for Altilis cookies is the sales of cookie products. The next element in the business model canvas is the Key Activities. Key Activities play an essential role in realizing the value proposition (Fitriani \& Sultan, 2019). This element can determine the success of a business through activities that will become the core of a business. Autistic preparations towards business development regarding the production of products to consumers. Essential Activities Altilis cookies maximize product marketing through advertisements on various social media and e-commerce, sharing uploads through social media and websites about autism, and GFCF (Gluten Free Casein Free) diet support foods.

Partner cooperation in a business is needed. The cooperative relationship takes place to benefit each other. Altilis cookies will partner with communities and specialty shops that sell autism food, especially in Greater Bandung. In addition, Altilis cookies will also collaborate with special schools by offering cookies products in the school canteens.

Cost Structure is the last element in the business model canvas. This element describes all the company's operational costs. Costs incurred by Altilis cookies in production costs, marketing with paid advertising through social media, website and internet development, and product and company legality costs.

\section{Conclusions}

The canvas business model is a business model used to help business actors develop their businesses more efficiently. The canvas business model's nine elements have an attachment that can be used as a guideline when making decisions.

Altilis cookies as a new startup requires an analysis of the canvas business model. Through this analysis business, actors can maximize resources to achieve maximum profit. In the canvas business model, which is the core of this business, which lies in the uniqueness of the product that does not only serve cookies but can be a means of education for children through packaging that can be scanned and connected to the official website of Altilis cookies, through this media parents can teach animals to eat. Animals to their children.

This canvas business model can 
help anyone who wants to start a business with careful analysis so that the company that will be undertaken has the right strategy and can be sustainable with a high profit value.

\section{References}

Al-Debei, M. M., \& Avison, D. (2010). Developing a Unified Framework of the Business Model Concept. European Journal of Information System, 19 (3), 359-376

Fatricia, W \& Mokh Adib, S. (2019). Implementasi Bisnis Model Kanvas dalam Perancangan Manajemen Bisnis Aplikasi JASAKOST. Jurnal Ilmu Manajemen dan Bisnis, 10 (1), 93-100

Fitriani R \& Mokh Adib, S (2019) Model Bisnis Kanvas Sebagai Solusi Inovasi Bagi Yang Kecil Bisnis. Jurnal Ilmu Manajemen dan Bisnis, 10 (2), 197-203

Haaker, T., Bouwman, H., Janssen, W., \& de Reuver, M. (2017). Business model stress testing: A practical approach to test the robustness of a business model. Futures, 89, 14-25.

Hartatik H \& Baroto T (2017). Strategi Pengembangan Bisnis dengan Metode Business Model Canvas. Jurnal Teknik Industri, 18 (2) 113-120.

Khoirunnisa L, Judiono. (2018). Gambaran Asupan Gluten dan Kasein pada Anak Penderita Autis di Klinik Tumbuh Kembang Anak Rumah Sakit Al-Islam Bandung. Jurnal Riset Kesehatan Poltekes Depkes Bandung, 10(1) 1-8

Kindstrom, D., \& Kowalkowski, C. (2014).Service innovation in productcentric firms: A multidimensional business model perspective. Journal of Business \& Industrial Marketing, 29(2), 96-111,

Kuswandi A, Sultan M. Penerapan Bisnis Model Kanvas Pada Social Marketplace Santree. Jurnal Ilmu Manajemen dan Bisnis, 11 (1): 181-185.

Narto, (2018). Pengembangan Bisnis
Model Kanvas untuk Meningkatkan Daya Saing Industri Batik Sumenep Madura. Prosiding Seminar Nasional \& Internasional, 207-215.

Nenonen, S., \& Storbacka, K. (2010), "Business model design: conceptualizing networked value co-creation," International Journal of Quality and Service Sciences, 2(1), 43 59,https://doi.org/10.1108/17566691011 02659

Nurhidayati Z, (2015) Pengaruh Pola Konsumsi Makanan Bebas Gluten Bebas Kasein dengan Gangguan Perilaku pada Anak Autistik. Jurnal Majority, 4 (7) 121-128.

Osterwalder, A.,\& Pigneur, Y. (2010). Business model generation: a handbook for visionaries, game-changers, and challengers. Jhon Wiley \& Sons. https://doi.org/7170621

Puspitha, Farsad C \& Berawi, Khairun N, (2016). Terapi Diet Bebas Gluten dan Bebas Casein pada Autism Spectrum Disorder (ASD). Jurnal Majority, 5 (1) 38-43

Simbolon, Cory Glorya, Putro Jawas Dwijo, Alhamdani, M.Ridha (2020). Autis Center dengan Pendekatan Healing Environment. Jurnal Mosaik Arsitektur. 8 (2), 505-520

Smedlund, A. (2012). Value co-creation in service platform business models. Service Science, 4(1), 79-88.

Sugiyono. (2013). Metode Penelitian Pendidikan, Penelitian Kuantitatif dan R\&D (pp. 1-16). CV. Alfabeta, Bandung. Tanjung, Yohana \& Kusnadi Joni (2015). Biskuit Bebas Gluten dan Bebas Kasein bagi Penderita Autism. Jurnal Pangan dan Agroindustri, 3 (1) 11-22

Wahyu Permata Sri Tunggal Djati, A. F. (2017). Hubungan Pola Konsumsi Gluten dan Kasein , Kepatuhan Diet Gluten Free Casein Free (GFCF) Dengan Perilaku Autis di Rumah Autis Bekasi. Jurnal AGRIPA, 75-88. 